\title{
Kisspeptin/GPR54 System: What Do We Know About Its Role in Human Reproduction?
}

\author{
Camila M. Trevisan ${ }^{a} \quad$ Erik Montagna $^{\mathrm{b}}$ Renato de Oliveira ${ }^{\mathrm{a}}$ Denise M. Christofolini ${ }^{\mathrm{a}}$ \\ Caio P. Barbosa ${ }^{a}$ Keith A. Crandallc Bianca Bianco ${ }^{a}$ \\ aHuman Reproduction and Genetics Center - Department of Collective Health, Faculdade de Medicina \\ do $A B C$, Santo André, 'D Division of Post Graduation, Faculdade de Medicina do ABC, Santo André, \\ Brazil, 'Computational Biology Institute, Milken Institute School of Public Health, George Washington \\ University, Washington, D.C., USA
}

\section{Key Words}

Kisspeptin • Human Reproduction • Infertility • KISS1 gene $•$ GPR54 gene • Dosage

\begin{abstract}
Kisspeptin is involved in the control of human reproduction bridging the gap between the sex steroid levels and feedback mechanisms that control the gonadotropin releasing hormone $(\mathrm{GnRH})$ secretion; however, studies considering this peptide and infertility are limited. We conducted a review and critical assessment of available evidence considering kisspeptin structure, physiology, function in puberty and reproduction, its role in assisted reproduction treatments, kisspeptin dosage and the impact on KISS1 and GPR54 genes. Literature searches were conducted in PubMed using keywords related to: (i) kisspeptin or receptors, kisspeptin-1 (ii) reproduction or infertility or fertility (iii) gene and (iv) dosage or measurement or quantification or serum level, in human. Kisspeptin is a product of KISS1 gene that binds to a G-protein-coupled receptor (GPR54/KISS1R) stimulating the release of GnRH by hypothalamic neurons, leading to secretion of pituitary gonadotropins (LH and FSH) and sexual steroids, which in turn will act in the gonads to produce the gametes. Kisspeptin is being recognized as a crucial regulator of the onset of puberty, the regulation of sex hormone mediated secretion of gonadotropins, and the control of fertility. Inactivating and activating mutations in both KISS1 or GPR54 genes were associated with hypogonadotropic hypogonadism and precocious puberty. Despite this, studies considering kisspeptin and infertility are scarce. The understanding of the role of kisspeptin may lead to its use as a biomarker in infertility treatments and use in controlled ovarian hyperstimulation.




\section{Cellular Physiology Cell Physiol Biochem 2018;49:1259-1276

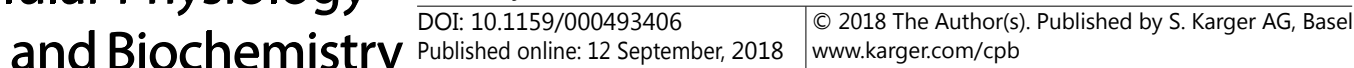 \\ Published online: 12 September, 2018 www.karger.com/cpb}

\section{Introduction}

Lee et al. [1] isolated the kisspeptin from melanoma cell lines and considered it as a 54-amino acid protein from a metastasis suppressor gene, officially named KISS1 (gene ID: 3814), located at 1q32. In 1999, a G protein coupled receptor (GPR54) was discovered as a member of galanin receptor family, although, this receptor did not show specific binding with galanin [2]. In 2001, independent groups announced that kisspeptin is a natural ligand of GPR54, as a consequence it is referred as kisspeptin receptor (KISS1R) [3-5].

Northern blot and in situ hybridization analyses revealed that GPR54 is expressed in brain regions (pons, midbrain, thalamus, hypothalamus, hippocampus, amygdala, cortex, frontal cortex, and striatum) as well as peripheral regions (liver, pancreas and intestine). GPR54 is also highly expressed in placenta, pituitary gland, pancreas, gonadotrophs, testicles, ovaries, and spinal cord, suggesting a role in the regulation of endocrine function [2, 3, 5-7].

First evidence related the KISS1/GPR54 system with reproductive control came from two distinct studies that noted mutations in GPR54 (KISS1R) (located at 19p13.3, gene ID: 9291) were associated with hypogonadotropic hypogonadism in humans, characterized by deficient luteinizing hormone ( $\mathrm{LH})$ and follicle stimulating hormone (FSH) secretion; leading to delay of reproduction function and infertility $[8,9]$. Similar effects were observed in transgenic mice that did not express Kiss1/Gpr54 and showed absence of sexual maturity, with hypo development of gonads, hypogonadotropic hypogonadism, and infertility [9].

Numerous studies have reported the involvement of kisspeptin(s) in the regulation of the hypothalamic-pituitary-gonadal (HPG) axis. The kisspeptin system is conserved among vertebrate species, except for the avian species; however, the general physiological functions of kisspeptin in vertebrates is still unclear. Here, we aimed to highlight aspects of kisspeptin related to the human reproduction system, focusing on human assisted reproduction.

\section{Methods}

Literature searches were conducted in Pubmed using the following keywords: (i) kisspeptin or receptors, kisspeptin-1, (ii) reproduction or infertility or fertility, (iii) gene and (iv) dosage or measurement or quantification or serum level. We found 460 articles related to reproduction and 69 articles related to dosage/measurement. We focused on articles related to kisspeptin role in human reproduction. We excluded reviews, comments and articles which main subject was animal reproduction, cancer, cell culture, embryos/ fetal development, social environment, behavior and stress. Animal models were used to corroborate with kisspeptin action in humans. A total of 107 articles were analyzed.

\section{Kisspeptin/GPR54 Structure}

The first transcript of KISS1 has 145 amino acids and is cleaved proteolytically delivering the most common form with 54 amino acids; other forms are: 14, 13 and 10-amino acid peptides. The post-translational proteolysis occur at two dibasic residues in pre-prokisspeptin (145 amino acid) at positions 66-67 and 123-124 [10] (Fig. 1).

The products from KISS1 are widely referred to "kisspeptins" as the peptides that possess the highly conserved 10 amino acid RF-amide $C$ terminus core sequence (kp-54, kp$14, \mathrm{kp}-13$ and kp-10) $[3,5,11,12]$. The last two amino acid are arginine and phenylalanine that receive an amine group transferred from glycine at position 122 to residue 121 which is the C-terminal end of mature peptide amino acid [10] (Fig. 1).

The decapeptide kp-10 has the minimal length to completely stimulate the GPR54 and consequently increases phosphatidylinositol turnover. For this reason, it is considered the main peptide $[9,13]$. GPR54 is a 398-amino acid protein of the Gq class of G proteins coupled to phospholipase C. GPR54 has an extracellular N-terminal domain that is followed 
by seven transmembrane helices and ends with a C-terminal cytoplasmic domain of about 70 residues $[9,13]$. Bianco and Kaiser [14] predicted the GPR54 structure in cellular membrane considering the amino acids sequence that result in a three intracellular and three extracellular loops, and seven transmembrane helices (Fig. 1).

This intracytoplasmic C-terminal region binds to the catalytic and regulatory subunits of phosphatase $2 \mathrm{~A}$ and can form complexes with protein partners involved in receptor signaling $[13,15]$. As consequence, GPR54 signal increases intracellular $\mathrm{Ca}^{2+}$ levels, activate calcium-

Fig. 1. Kisspeptin and GPR54 protein structure from human. (A) Pre-prokisspeptin and path of proteolytic cleavage, resulting in active kisspeptins (kp-54, kp-14, kp13 and kp-10). $\mathrm{Kp}-10$ has the minimal-length for completely stimulate the GPR54 (B) GPR54 structure from SWISS-MODEL (Q969F8 - KISSR_HUMAN)[106] (C) GPR54 structure illustrated in plasma membrane with seven transmembrane helices, an extracellular N-terminal domain and ends with C-terminal cytoplasmic domain.

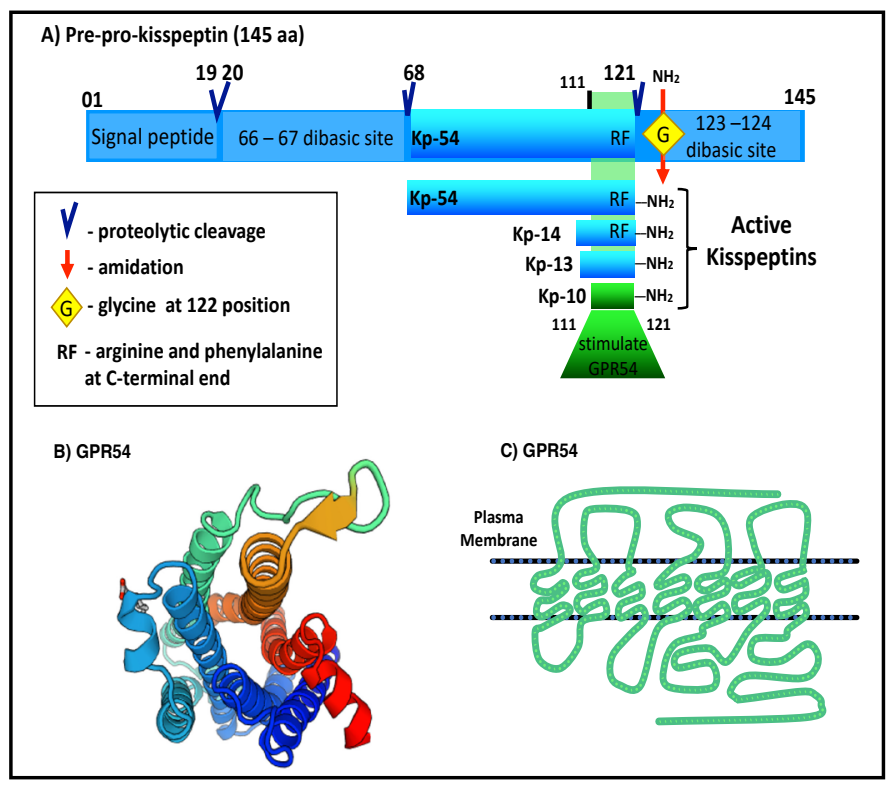

Fig. 2. Kisspeptin/ GPR54 cellular signaling and physiologic role in menstrual cycle. A) GPR54 and intracellular signaling. The GPR54 is coupled to $\mathrm{G}_{\mathrm{q} / 11}$ protein, when kisspeptin stimulates its receptor, the $G_{q / 11}$ activates phospholipase $\mathrm{C}\left(\mathrm{PLC}_{\beta}\right)$ that hydrolyzes phosphatidylionositol 4,5-bisphosphate producing messengers:

(PIP $\left.{ }_{2}\right)$ second 1,4,5-trisphospate $\left(\mathrm{IP}_{3}\right)$ and

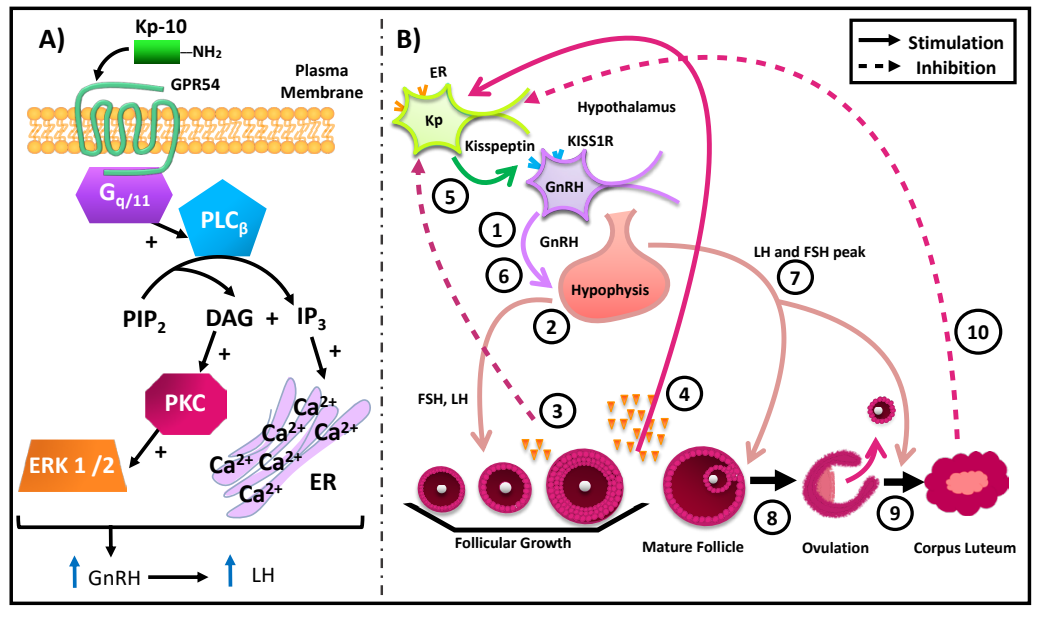
diacylglycerol (DAG). IP ${ }_{3}$ stimulates the endoplasmic reticulum (ER) to mobilizes calcium $\left(\mathrm{Ca}^{2+}\right)$. Increasing intracellular $\mathrm{Ca}^{2+}$ levels activate calcium-dependent signaling pathways in GnRH neurons. DAG activates calcium-dependent protein kinase C (PKC) that activates extracellular signal-regulated kinases 1 and 2 (ERK1 and ERK2). B) The kisspeptin role in LH pulse. GnRH stimulates the hypophysis (1) that releases FSH and LH (2), which stimulates the follicular growth and begin to produce estradiol (3). The estradiol suppresses hypothalamic-pituitary-gonadal axis (3). In late follicular phase when main follicle achieves around $12 \mathrm{~mm}$ estradiol level increase and stimulates the kisspeptin (Kp) neurons which have an estradiol receptor (ER) releasing the kisspeptin (4). Kp neurons stimulate the GnRH neurons (5) that induces the LH release (7), ovulation (8) and corpus luteum development (9). Corpus luteum produces progesterone, estradiol and inhibin A that inhibit the hypothalamic-pituitary-gonadal axis (10). 


\section{Cellular Physiology Cell Physiol Biochem 2018;49:1259-1276 \begin{tabular}{ll|l} 
and Biochemistry Published online: 12 September, 2018 & $\begin{array}{l}\text { (c) } 2018 \text { The Author(s). Published by S. Karger AG, Basel } \\
\text { www.karger.com/cpb }\end{array}$ \\
\hline
\end{tabular}

dependent signaling pathways and activates mitogen-activated protein kinases (MAPK) p38, extracellular signal-regulated kinases 1 and 2 (ERK1 and ERK2) in GnRH neurons [3] (Fig. 2). In mice, kisspeptins have been reported to act on gonadotropin-releasing hormone (GnRH) neurons directly, by acting on some intrinsic ion channels producing a strong persistent depolarization $[16,17]$.

Kisspeptins not only increase the GnRH secretion, but also increases GnRH expression, as demonstrated in neuronal cell lines (GT1-7 and GN11 cell) [18]. In mouse the Gnrh gene was observed as a kisspeptin response element between $-3446 \mathrm{bp}$ and $-2806 \mathrm{bp}$ that participate in Gnrh expression regulation. In addition, GT1-7 cells treated with kisspeptin significantly increased total histone 3 acetylation (H3Ac). It demonstrated an histonedependent transcription activation and chromatin conformation mediated by kisspeptin [19].

\section{Function in puberty and reproductive system}

The KISS1/GPR54 system is essential to signal for increased gonadotrophin secretion during puberty and to establish mammalian reproductive function and regulation of the HPG axis [20,21]. KISS1 expression is negligible in prepubertal ovaries and abruptly increases at the time of preovulatory surge of gonadotropins [22]. As consequence, kisspeptin administration in immature rodents and primates was able to induce precocious activation of the gonadotropic axis and precocious pubertal development [23-25]. Additionally, kisspeptin levels are higher in girls with central precocious puberty [26, 27]. In gonadal juvenile male monkeys, however, the continued kisspeptin administration decreases the LH levels, consequently leading to the assumption that kisspeptin secretion is pulsatile, and the continuous stimulation may induce receptor desensitization [28, 29].

Mutations in KISS1/GPR54 genes result in a great diversity of phenotypes from partial sexual development to severe hypogonadism. This demonstrated that kisspeptin is essential in all phases of development. In fetal development GnRH secretion is required for testicular descent and penile growth. Mutations in GPR54 results in micropenis and/or cryptorchidism. In neonatal life and puberty kisspeptins stimulate GnRH secretion, gonadotropin maintenance levels and loss-of-function mutations leads to an absence of pubertal development [30]. Mutations in KISS1/GPR54 could cause infertility in men and women, therefore hormone replacement (usually $\mathrm{GnRH}$ ) repaired the reproductive function [31, 32].

Human spermatozoa expresses KISS1, kisspeptin was located at post-acrosomal region of the sperm head and GPR54 was mainly found in the equatorial segment of the sperm head and around the neck, both demonstrated by immunodetection and the presence of GPR54 was confirmed by western blot [33]. Different status of fertility showed different levels of serum kisspeptin. Fertile men showed significantly higher kisspeptin serum levels compared to infertile men with diverse problems in spermatogenesis [34]. Kisspeptin levels were higher in four men with hypogonadism than in fertile controls. After GnRH treatment the serum kisspeptin decreased suggesting that elevated kisspeptin levels were a consequence of lower negative feedback of gonadal steroids in hypogonadism [35].

Kisspeptin exerts an important stimulatory role in the genesis of LH preovulatory peak [36-39], which is responsible for ovulation deflagration in females. In the nervous system, kisspeptin neurons were connected to GnRH neurons and experiments showed that central or peripheral administration of kisspeptin exerts a potent stimulatory effect on gonadotrophins secretion [40]. It was noted that low doses of intracerebroventricular kisspeptin markedly increased LH and FSH secretion [41, 42]. This occurs through the activation of GnRH neurons, which express GPR54 [43-45]. The same results were observed in sheep [46], monkeys $[24,28]$ and humans $[47,48]$.

In mice, kisspeptin regulates the prolactin release through the inhibition of hypothalamic dopaminergic neurons, whereas this mechanism depends on estradiol in female rodents 
[49]. These results confirm the important role played by kisspeptin in physiological regulation of $\mathrm{HPG}$ axis.

Sex steroid sensitivity of kisspeptin expressing neurons appears to be conserved among mammals [37, 50] suggesting that this sensitivity is a general feature of all kisspeptin systems among vertebrates. It also indicates that KISS1 neurons mediate sex steroid feedback effects in placental mammals; these neurons receive sex steroid signals from the gonads and modulate the activity of GnRH neurons (Fig. 2) [16, 17].

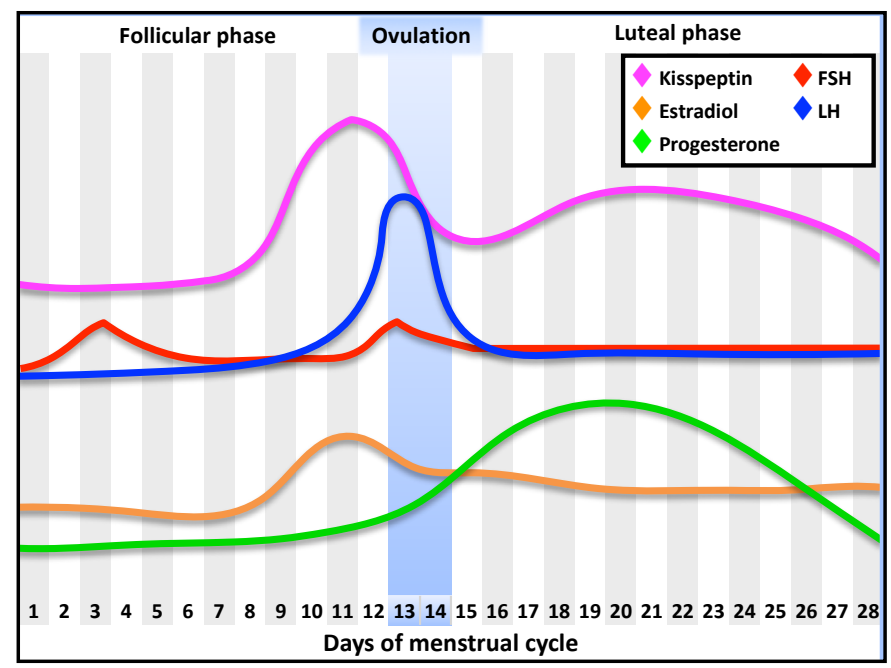

Fig. 3. Kisspeptin levels during menstrual cycle. Neurons that directly receive sex steroids and control the GnRH release (mediators of sex steroid feedback) have been researched because GnRH neuron lacks estrogen receptor alpha [51], which is essential for sex steroid control of reproduction [52]. At the same time, positive or negative steroid feedback regulation can be changed rather easily by the composition of co-expressing transcription factors [53].

Even though kisspeptin was used for in vitro fertilization (IVF) treatments, such knowledge is not yet established in the menstrual cycle. Kisspeptin levels increase from early follicular to preovulatory phase and from preovulatory to luteal phase [54, 55], which along with previous data about menstrual cycle guided the Fig. 3 construction. The relation among kisspeptin and follicular growth was tested and the peak was found on the 11th day when the dominant follicle was approximately $1.2 \mathrm{~cm}$. These data suggest a new role for kisspeptin dosage as a potential predictor of follicle development and ovulation [55].

In addition, kisspeptin is associated with follicular maintenance in ovarian tissues. Mural granulosa cells and cumulus cells were collected at oocyte retrieval from oocyte donors in IVF treatment. These cells expressed KISS1 and GPR54 observed by mRNA levels and immunofluorescence that showed kisspeptin presence in cytoplasm and cell nuclei and GPR54 in cytoplasm and cell membrane. These results were also confirmed by western blot. KISS1 mRNA was more expressed in cumulus cells than in mural granulosa cells [56].

Moreover, mutant mice with Gpr54 haploinsufficiency developed premature ovarian failure phenotype. These mice did not show differences in preantral follicle development (3 weeks), that was estimated by total number and morphologic features, between wild type (WT) and Gpr54+/- mice (before puberty). However, in later postnatal ages Gpr54+/- mice showed a progressive deterioration of ovarian architecture. By 32 weeks of age, follicle loss became firmly established in Gpr54+/- mice ovaries showing a reduced number of both antral and preantral follicles [22].

Taking into account the participation of kisspeptins in folliculogenesis pharmacokinetic studies was developed. Kp-54 and kp-10 have had the similar activities when added to cell culture. However, kp-54 had a longer onset and more duration of action than kp-10 in the same molar concentration in rodents [57]. Pharmacokinetic studies of kisspeptin in humans did not find consensus about the administration route (intravenous bolus, intravenous infusion and subcutaneous bolus) and which kisspeptin type should be used (kp54 or kp10)[57].

$\mathrm{Kp}-10$, when administrated as intravenous bolus or subcutaneous bolus, had a detection peak at $15 \mathrm{~min}$ in both cases; although, degradation was different, undetectable by $30 \mathrm{~min}$ and declined to baseline over 45-120 min (half-life approximately $20 \mathrm{~min}$ ), respectively. 
Kp-10 administrated as intravenous infusion showed a half-life approximately 4 min after infusion stopped [58]. Administration of kp-54 as an intravenous bolus in women or men has a peak at $40 \mathrm{~min}$ and $30 \mathrm{~min}$, respectively. In women it disappeared after $3 \mathrm{~h}$ and in men it has a half-life 28 min $[47,58]$. Kisspeptin subcutaneous bolus has peak at $15 \mathrm{~min}$ and disappeared after $3.5 \mathrm{~h}$ [59]. In vitro, $\mathrm{kp}-54$ added to human plasma showed half-life $55 \mathrm{~s}$ [60].

Also, kisspeptin administration showed different responses across the menstrual cycle. In the preovulatory phase, the LH pulses increased immediately after an administration of single bolus at $0.24 \mathrm{nmol} / \mathrm{kg}$ of $\mathrm{kp}-10$. In luteal phase a discrete increase of FSH and estradiol also was observed. Although in early follicular phase there were a variety of responses (only half women increase LH levels) [61]. The same was observed in administration of a subcutaneous bolus of kp-54 (at $0,0.2,0.4,0.8,1.6,3.2$, and $6.4 \mathrm{nmol} / \mathrm{kg}$ concentrations) in women with regular menstrual cycle, that leaded to potent elevation of LH release specially in preovulatory phase [59]. In healthy men, intravenous bolus injection of $\mathrm{kp}-10$ (at doses: $0.3,1.0,3.0$, or $10 \mathrm{nmol} / \mathrm{kg}$ ) stimulated FSH, LH and testosterone release, specially LH [47, 58]. However, kp-10 and kp-54 intravenous infusion did not achieve the same stimulation of gonadotropins that $\mathrm{GnRH}$ produces [62].

In addition, purified native forms of kisspeptins in various vertebrate species are less used and attention is needed to interpreting physiological experiments with $\mathrm{kp}-10$ as kisspeptin ligands since there may exist other slightly different physiological functions of the natural peptides [12].

\section{Human reproduction treatments}

Infertility is a public health issue that affects $15-20 \%$ of couples at reproductive age [63]. Among the causes of infertility, the main are advanced female age, tubal obstruction and polycystic ovarian syndrome (PCOS). KISS1 and GPR54 are expressed in human uterus (endometrium), ovary and oviduct at both mRNA and protein levels [64]. However, the peripherical kisspeptin/GPR54 system function is not clear yet.

Mentioned above, kisspeptin is essential to ovary maintenance and there is evidence that women in distinct reproductive status had different responses to kisspeptin. Intravenous administration of kp-10 in women increased LH in follicular phase ( $6.3 \pm 1.2$ to $9.4 \pm 1.3 \mathrm{IU} / \mathrm{L})$, postmenopausal $(35.3 \pm 2.8$ to $44.7 \pm 3.4 \mathrm{IU} / \mathrm{L})$ and combined oral contraceptive pill $(2.2 \pm 0.9$ to $3.7 \pm 1.4 \mathrm{IU} / \mathrm{L}$ ] [65]. Therefore, it is necessary to conducted more studies about kisspeptin levels and signaling during female reproductive life whereas women are becoming pregnant older. Also, PCOS was associated with higher levels of KISS1 expression and there is a positive correlation of kisspeptin and LH levels in these patients, suggesting that kisspeptin contributes to hypersecretion of LH which participates in the pathophysiology of this syndrome $[66,67]$.

The use of in vitro fertilization (IVF) allows treatment of some aspects of infertility. In developed countries, it is estimated that 2-3\% of all births are results of IVF procedures [68]. IVF is a complex process involving several steps, including puncture of oocyte containing follicles following controlled ovarian hyperstimulation $(\mathrm{COH})$ with recombinant FSH ( $\mathrm{rFSH}$ ), oocyte fertilization, embryo development, embryo transfer to the uterus, and implantation. All of these steps are crucial to the IVF procedure success. However, the first important step is the ovarian response to controlled ovarian hyperstimulation, whose objective is obtain a satisfactory number of mature oocytes; thus, allowing the selection of the most viable embryo for transfer.

The standard protocol in young normoovulatory women can result both in satisfactory or unsatisfactory responses, such as hyper response, poor respondse, and Ovarian Hyper Stimulation Syndrome (OHSS), which requires the rFSH dose adjustment. OHSS is an IVF 


\section{Cellular Physiology Cell Physiol Biochem 2018;49:1259-1276 \\ \begin{tabular}{ll|l} 
and Biochemistry & $\begin{array}{l}\text { DOI: 10.1159/000493406 } \\
\text { Published online: 12 September, } 2018\end{array}$ & $\begin{array}{l}\text { (c) } 2018 \text { The Author(s). Published by S. Karger AG, Basel } \\
\text { www.karger.com/cpb }\end{array}$ \\
\hline
\end{tabular} \\ Trevisan et al.: Insights into Kisspeptin/GPR54 System}

complication characterized by multiple ovarian follicles ( $\geq 20$ follicles) together with possible clinical symptoms, such as ascites, hematological changes (hemoconcentration), pleural effusion, liver and/or coagulation abnormalities, besides $\geq 4000$ IU of serum estradiol, according to the classification proposed by Golan et al. [69]. Severe ovarian hyperstimulation is observed in approximately $0.6 \%$ of $\mathrm{COH}[70]$.

Considering this variability of ovarian response to exogenous gonadotrophins administration in IVF treatments, it is necessary to search ways to prevent the adverse effects. Abbara et al. [71] conducted a phase 2, multidose, open-label, randomized clinical trial of 60 women at high risk of OHSS using kp-54 to trigger oocyte maturation and prevent the OHSS. They noted oocyte maturation and embryo formation in $95 \%$ and $90 \%$, respectively, of women who received kisspeptin. The highest pregnancy rate was founded in $9.6 \mathrm{nmol} /$ $\mathrm{kg} \mathrm{kp}-54$. Also, the OHSS was observed only in 7\% (four woman), however did not have moderate, severe, or critical OHSS.

Previously the same group tested a single subcutaneous injection of kp-54 to induce LH surge and egg maturation with different concentrations. They observed that oocyte retrieval was difficult in the $1.6 \mathrm{nmol} / \mathrm{kg}$ and $3.2 \mathrm{nmol} / \mathrm{kg}$ groups; therefore, they used $6.4 \mathrm{nmol} / \mathrm{kg}$ and $12.8 \mathrm{nmol} / \mathrm{kg}$ doses to induce the oocyte maturation. This approach resulted in $92 \%$ of fertilized oocytes and $58 \%$ of high-quality embryos. Kisspeptins were considered safe and well tolerated by patients [72].

Furthermore, patients with high risk of OHSS (AMH $\geq 5.6 \mathrm{ng} / \mathrm{mL}$ or total antral follicle count $\geq 23$, age 18-34 years) were stimulated using daily recombinant FSH injection (112, 5 IU of recombinant FSH) and a new protocol was tested comparing single or double subcutaneous injection of kisspeptin-54 $(9.6 \mathrm{nmol} / \mathrm{kg})$. The injections were administrated when at least three ovarian follicles $\geq 18 \mathrm{~mm}$ diameter at $36 \mathrm{~h}$ prior to oocyte retrieval and double subcutaneous injection was administrated at $36 \mathrm{~h}$ prior to oocyte retrieval and 10 $\mathrm{h}$ after first injection. The number of patients achieving $\geq 60 \%$ oocyte yield was $45.2 \%$ and $71.0 \%$ in single and double injection, respectively. In addition pregnancy rate was bigger in double injection group (23.0\% x 39.0\%) [73]. The data suggest that kisspeptin could be an alternate oocyte trigger preventing OHSS and resulting in a satisfactory pregnancy rate, especially for women with OHSS risk.

\section{Kisspeptin on implantation and pregnancy}

When kisspeptin was discovered it was called metastin, which was considered a metastasis suppressor [1], due to its capacity to inhibit cell invasion, altering cell motility and/or adhesion [5]. These properties were essential in embryo implantation as it is a critical step for reproduction success. The nidation is based on trophoblast invasion of the uterine extracellular matrix. It is known that kisspeptin is a factor that together with other proinflammatory cytokines, particularly $\mathrm{TNF} \alpha$, constrain trophoblast invasion and may play a role in the time of delivery, modulating the trophoblast apoptosis [74].

Immunohistochemical and Real Time Polymerase Chain Reaction (RT-PCR) analyses showed presence of KISS1 and GPR54 expression in the human ovary, the oviduct, and the uterus (luminal and glandular epithelial cells from endometrium), suggesting a kisspeptin role in the regulation of epithelial functions [64]. The expression of mRNA signatures of trophoblast cells isolated from first trimester (high invasiveness) and term (no/low invasiveness) placenta showed that KISS1 and GPR54 were highly expressed in first trimester trophoblasts compared to term gestation. $\mathrm{Kp}-10$ increased intracellular $\mathrm{Ca}^{2+}$ levels in isolated first trimester trophoblasts emphasizing Kp-10 as a paracrine/endocrine regulator in finetuning trophoblast invasion generated by the trophoblast itself [75]. Corroborating these results, the same was found in canine pregnant uterus and trophoblast cells [76].

Unmated but cycling mice females did not respond to kp-54 injection suggesting that Gpr54 is weakly expressed in nonpregnant uterus [77]. Kiss1-/- female mice were unable to achieve pregnancy due to implantation failure, independently of gonadotropins replacement 
and estradiol that restores ovulation and fertilization. The implantation of embryos transferred from Kiss1-/- mothers to wild ones demonstrated that is maternal defect [78].

The injection of kp-54 in pregnant mice triggers the signal of MAPK p38 and ERK1/2 phosphorylation on the day of embryo implantation (D4 after of pregnancy), emphasizing that Kiss1/Gpr54 prepare the stromal cells for decidualization and reinforces the kisspeptin role as a paracrine signaling [77].

In women, there is evidence that kisspeptin levels increase each trimester during pregnancy [79] and it could reach a 200-fold higher level in the third trimester when compared with nonpregnant women [80]. Kisspeptin levels below $1630 \mathrm{pmol} / \mathrm{L}$ during the first trimester were considered a miscarriage biomarker, since women who suffer miscarriages show kisspeptin levels $60 \%$ lower than unaffected pregnancies [81].

In addition, low levels of kisspeptin in the second trimester (16 - 20 weeks) were associated with intrauterine growth restriction [82], while low levels in early and late pregnancy were associated with preeclampsia [82, 83]. These alterations should be considered in fetus development since intrauterine environment, preterm, epigenetic mechanisms and parental programing could participate of diseases development in later life [84], for example, intrauterine environmental factors are linked to the development of cardiovascular disease in later life [85] and alterations in maternal or fetal metabolism are associated with birth weight [86].

In intracytoplasmic sperm injection (ICSI) treatments, kisspeptin levels on the day of human chorionic gonadotropin (hCG) administration were correlated with pregnancy rate. Kisspeptin was higher in the pregnant group with fetal heart beat than the nonpregnant group. However, this result should be interpreted with cation, since the pregnant group also presented better embryo quality [87].

\section{Dosage}

Kisspeptin dosage is currently measured by diverse analytical methods without standard values and limited data, which leads to an absence of consensus (Table 1). Even though its dosage was done in different health conditions and measured looking for biomarker in women submitted to IVF [88] and patients with cancer [89, 90]; also was used to investigate fertility status [91]; polycystic ovary syndrome [92]; hypertensive diseases in pregnant women [93] and metabolism such as kisspeptin impact in insulin release and obesity [94-96].

Among analytical detection methods monoclonal assays were not capable of detecting kisspeptin inactive forms, but polyclonal assays could reduce this bias; however, some part of the studies did not specify which molecule was dosed. On the other hand, mass spectrometry seems to overcome many limitations, since it identifies the intact isoforms and their metabolites [57].

Ramachandran et al. [97] evaluated different anticoagulants (lithium heparin with 2000 U trasylol, citrate, EDTA, serum clot activator, and serum separator tubes) as a pre-analytical factor that could affect radioimmunoassay (RIA) measurements of kisspeptin serum levels. They observed that an EDTA solution preserve the sample better than traysol, citrate and serum separator. Kisspeptin immunoreactivity concentrations did not significantly change even after repeated freezing. However, this study was conducted using only pregnant women who have a significant increase of kisspeptin levels.

Non-invasive methods were tested considering that kisspeptin is a small oligopeptide and can pass through the glomerular filtration membrane, being able to be test in urine and saliva samples [55]. In nonpregnant women, there is evidence that serum and urine samples are equivalent. Saliva samples differ considerably from serum and urine samples and cannot be considered as an alternative sample [55].

Kisspeptin-10 added to human plasma showed a half-life of 55 seconds in vitro, revealing 


\begin{tabular}{|c|c|}
\hline Cellular Physiology & Cell Physiol Biochem 2018;49:1259-1276 \\
\hline and Biochemistr & 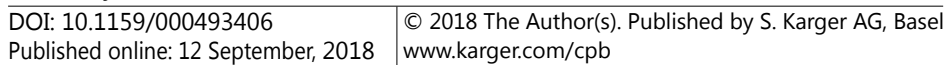 \\
\hline
\end{tabular}

Table 1. Dosage of kisspeptin by different methodologies and clinical conditions. \# Kisspeptin results were converted to $\mathrm{ng} / \mathrm{mL}$ for comparison purposes. * median and percentile (25-75) were showed. BMI: body mass index; POS: Polycystic Ovary Syndrome; CCR: Colorectal Cancer; SST: Serum Separator Tube; PHI: Pregnancy-Induced Hypertension

\begin{tabular}{|c|c|c|c|c|c|c|c|}
\hline Condition & Authors & Study brief description & Methodology & \multicolumn{4}{|c|}{ Condition and results (mean \pm SD)\# } \\
\hline \multirow{6}{*}{$\begin{array}{l}\text { Kisspeptin collected } \\
\text { considering different } \\
\text { phases of menstrual } \\
\text { cycle }\end{array}$} & \multirow{2}{*}{$\begin{array}{l}\text { Latif \& Rafique } \\
\text { [54] }\end{array}$} & \multirow{2}{*}{$\begin{array}{l}\text { Serum kisspeptin during the } \\
\text { menstrual cycle in } 30 \text { women ( } 18 \\
-25 \text { years old). }\end{array}$} & \multirow{2}{*}{$\begin{array}{l}\text { ELISA kit. Blood collected between } 8-10 \text { am, clotted } \\
\text { sample, centrifuged within } 30 \mathrm{~min} \text { and frozen at }-80^{\circ} \mathrm{C} \text {. }\end{array}$} & $\begin{array}{l}\text { Follicular } \\
\text { phase }\end{array}$ & $\begin{array}{l}\text { Pre- } \\
\text { ovulatory }\end{array}$ & \multicolumn{2}{|l|}{$\begin{array}{l}\text { Luteal } \\
\text { Phase }\end{array}$} \\
\hline & & & & $\begin{array}{l}343.99 \\
\pm 37.02\end{array}$ & $\begin{array}{l}\text { pnase } \\
615.36 \\
\pm 23.21\end{array}$ & \multicolumn{2}{|l|}{$\begin{array}{l}944.01 \\
\pm 48.00\end{array}$} \\
\hline & Rafique \& Latif & $\begin{array}{l}\text { Serum kisspeptin levels in } 14 \\
\text { women with BMI } 18.5-24.99 \text { and }\end{array}$ & ISA kit. Blood collected between 8-10 am & $\begin{array}{l}\text { Follicular } \\
\text { phase }\end{array}$ & $\begin{array}{l}\text { Pre- } \\
\text { ovulatory } \\
\text { phase }\end{array}$ & \multicolumn{2}{|l|}{$\begin{array}{l}\text { Luteal } \\
\text { Phase }\end{array}$} \\
\hline & & between 18 and 25 years old. & within $30 \mathrm{~min}$ and froz & $\begin{array}{l}338.38 \\
\pm 26.70\end{array}$ & $\begin{array}{l}584.02 \\
\pm 32.04\end{array}$ & \multicolumn{2}{|l|}{$\begin{array}{l}922.40 \\
\pm 64.47\end{array}$} \\
\hline & & Kisspeptin collected in 15 women & SS ELLSA kit & 3rd day & 11 th day & \multicolumn{2}{|l|}{ 14th day } \\
\hline & Zhai et al. [55] & $\begin{array}{l}\text { submitted to IVF due male } \\
\text { infertility between } 23 \text { and } 35 \\
\text { years old. }\end{array}$ & $\begin{array}{l}\text { Collection in the morning, centrifug } \\
\text { at }-80^{\circ} \mathrm{C} \text { collects in specific days. }\end{array}$ & $\begin{array}{l}0.23 \\
\pm 0.03\end{array}$ & $\begin{array}{l}0.51 \\
\pm 0.12\end{array}$ & \multicolumn{2}{|l|}{$\begin{array}{l}0.40 \\
\pm 0.16\end{array}$} \\
\hline \multirow{3}{*}{$\begin{array}{l}\text { Kisspeptin collect in } \\
\text { follicular phase of } \\
\text { menstrual cycle }\end{array}$} & $\begin{array}{l}\text { Mumtraz et al. } \\
{[88]}\end{array}$ & $\begin{array}{l}\text { Kisspeptin dosage in } 124 \text { women } \\
\text { ( } 32.2 \pm 4.8 \text { years old) submitted to } \\
\text { IVF associated with pregnancy } \\
\text { results. }\end{array}$ & $\begin{array}{l}\text { KISS-1-ELISA kit (Shanghai, China). Serum collection on } \\
\text { second day of menstrual cycle before begin the IVF } \\
\text { treatment. }\end{array}$ & $\begin{array}{l}\text { Pre-clinic } \\
\text { abortion } \\
0.22 \\
\pm 0.03\end{array}$ & $\begin{array}{l}\text { Clinical } \\
\text { pregnancy } \\
0.30 \\
\pm 0.01\end{array}$ & $\begin{array}{l}\text { Male } \\
\text { infertility } \\
0.40 \\
\pm 0.06\end{array}$ & $\begin{array}{l}\text { Female } \\
\text { infertility } \\
0.26 \\
\pm 0.02\end{array}$ \\
\hline & & Kisspeptin lev & $\begin{array}{l}\text { Kp-54 ELISA kit (Bioscience, Netherlands). Serum collect } \\
\text { in follicular phase ( } 3-5 \text { day) and randomly in amenorrhea, }\end{array}$ & $\begin{array}{l}\text { General } \\
\text { dosage* }\end{array}$ & Typical AN* & \multicolumn{2}{|c|}{ Non-typical AN* } \\
\hline & ${ }^{*}[91]$ & $\begin{array}{l}\text { (12-20 years old) with anorexia } \\
\text { nervosa (AN) and amenorrhea. }\end{array}$ & $\begin{array}{l}\text { let } 20 \mathrm{~min} \text { row temperature, centrifuge } 20 \mathrm{~min} \text { at } 3000 \mathrm{~g} \text {, } \\
\text { stored }-80^{\circ} \mathrm{C} \text {. }\end{array}$ & $\begin{array}{l}0.23 \\
(0.10-0.71)\end{array}$ & $\begin{array}{l}0.21 \\
(0.11-0.60)\end{array}$ & \multicolumn{2}{|l|}{$\begin{array}{l}0.44 \\
(0.17-0.64)\end{array}$} \\
\hline $\begin{array}{l}\text { Kisspeptin collect in } \\
\text { women }\end{array}$ & Chen et al. [27] & $\begin{array}{l}\text { Plasma kisspeptin levels in } \\
\text { adolescent }(\mathrm{n}=19) \text { and women } \\
(\mathrm{n}=23) \text { with PSO and healthy } \\
\text { teenagers }(\mathrm{n}=20) \text {. }\end{array}$ & $\begin{array}{l}\text { ELISA kit kp-54 (Phoenix Pharmaceuticals Inc., USA). } \\
\text { Plasma collect at } 9 \text { am, sample extraction before dosage. }\end{array}$ & $\begin{array}{l}\text { Health } \\
\text { teenagers }\end{array}$ & $\begin{array}{l}\text { POS } \\
\text { teenagers } \\
\text { Undetectable }\end{array}$ & \multicolumn{2}{|l|}{$\begin{array}{l}\text { PSo } \\
\text { women }\end{array}$} \\
\hline $\begin{array}{l}\text { Kisspeptin collect in } \\
\text { adults }\end{array}$ & $\begin{array}{l}\text { Andreozzi et al. } \\
{[94]}\end{array}$ & $\begin{array}{l}\text { Plasma kisspeptin levels in adults } \\
\text { ( } 216)(47 \pm 13 \text { years old), } 137 \\
\text { men. } \\
\text { Kisspeptin in men with prostatic }\end{array}$ & $\begin{array}{l}\text { EIA kit Kp-10 (Phoen ix Pharmaceuticals Inc. USA). } \\
\text { Plasma kisspeptin. }\end{array}$ & $\begin{array}{l}1 \text { st tercile } \\
0.33 \\
\pm 0.07 \\
\text { Patients }\end{array}$ & $\begin{array}{l}2 \text { nd tercile } \\
0.62 \\
\pm 0.14 \\
\text { Controls }\end{array}$ & \multicolumn{2}{|l|}{$\begin{array}{l}3 \text { rd tercile } \\
1.80 \\
\pm 0.71\end{array}$} \\
\hline \multirow{2}{*}{$\begin{array}{l}\text { Kisspeptin collected } \\
\text { in patients with } \\
\text { cancer }\end{array}$} & Curtis et al. [89] & $\begin{array}{l}\text { carcinoma and controls with } \\
\text { other kinds of cancer. }\end{array}$ & $\begin{array}{l}\text { RIA kit all kisspeptins } \\
\text { No information about collect }\end{array}$ & \multicolumn{2}{|c|}{ Undetectable } & & \\
\hline & $\begin{array}{l}\text { Canbay et al. } \\
{[90]}\end{array}$ & $\begin{array}{l}\text { Kisspeptin levels in } 88 \text { patients } \\
\text { with CCR ( } 57.9 \pm 11.75 \text { years old) } \\
\text { and } 59 \text { healthy controls ( } 57.1 \pm \\
7.44 \text { years old). }\end{array}$ & $\begin{array}{l}\text { ELISA kit kp }-54 \text { (Phoenix Pharmaceuticals Inc., USA). } \\
\text { Blood collect in EDTA }(1 \mathrm{mg} / \mathrm{ml} \text { ) tube, centrifuge at } 1600 \mathrm{~g} \\
\text { for } 25 \mathrm{~min} \text { at } 4^{\circ} \mathrm{C} \text {, storage at }-80^{\circ} \mathrm{C} \text { and kisspeptin } \\
\text { extraction before dosage. }\end{array}$ & $\begin{array}{l}\text { CCR group } \\
86.20 \\
\pm 20.50\end{array}$ & $\begin{array}{l}\text { Control } \\
\text { group } \\
49.00 \\
\pm 12.70\end{array}$ & & \\
\hline \multirow{11}{*}{$\begin{array}{l}\text { Kisspeptin collected } \\
\text { in pregnant women }\end{array}$} & \multirow[b]{2}{*}{$\begin{array}{l}\text { Ramachandran } \\
\text { et al. [97] }\end{array}$} & Preanalytical factors affecting RIA & \multirow{2}{*}{$\begin{array}{l}\text { RIA kit kp-54. Samples processed in different tubes } \\
\text { (lithium heparin with } 2000 \mathrm{U} / \text { tube of trasylol, citrate, } \\
\text { EDTA and SST and times }(0 \text { and } 4 \mathrm{~h}) \text {. }\end{array}$} & A 0 & SST oh & EDTA 4h & SST $4 \mathrm{~h}$ \\
\hline & & $\begin{array}{l}\text { measurement of kisspeptin in } \\
\text { four pregnant ( } 27 \pm 8.83 \text { weeks } \\
\text { women). }\end{array}$ & & $\begin{array}{l}35.73 \\
\pm 12.89\end{array}$ & $\begin{array}{l}8.79 \\
\pm 3.51\end{array}$ & $\begin{array}{l}20.50 \\
\pm 7.61\end{array}$ & Undetectable \\
\hline & \multirow{2}{*}{$\begin{array}{l}\text { Horikoshi et al. } \\
{[79]}\end{array}$} & $\begin{array}{l}\text { Kisspeptin concentrations in men } \\
\text { (12), women (10) and pregnant }\end{array}$ & \multirow{2}{*}{$\begin{array}{l}\text { In house ELISA ki. It used refrigerated tube with EDTA } \\
(1 \mathrm{mg} / \mathrm{mL}) \text { collected between } 9-12 \mathrm{am} \text {. Sample centrifuged } \\
1000 \mathrm{~g} \times 25 \mathrm{~min} \text { at } 44^{\circ} \mathrm{C} \text { stored at }-80^{\circ} \mathrm{C} \text { and diluted to } \\
\text { dosage. }\end{array}$} & $\begin{array}{l}\text { Men and } \\
\text { women }\end{array}$ & nester & $\begin{array}{l}2^{\text {nd }} \\
\text { trimester }\end{array}$ & $3^{\text {rd }}$ trimester \\
\hline & & $\begin{array}{l}\text { women in } 1^{\text {st }}\left(11=G(1) ; 2^{\text {nd }}\right. \\
(16=\mathrm{G} 2) \text { and } 3^{\text {rd }} \text { trimester } \\
(12=\mathrm{G} 3) \text {. }\end{array}$ & & Undetectable & $\begin{array}{l}1.60 \\
\pm 0.45\end{array}$ & $\begin{array}{l}5.98 \\
\pm 0.72\end{array}$ & $\begin{array}{l}12.49 \\
\pm 2.14\end{array}$ \\
\hline & Nijher et al. [93] & $\begin{array}{l}\text { Kisspeptin concentrations in } \\
\text { pregnant woman (78), women } \\
\text { with PIH (19) or pre-eclampsia } \\
\text { (8). }\end{array}$ & $\begin{array}{l}\text { RIA kit KP-54. Blood samples were collected into lithium- } \\
\text { heparin tubes containing } 5000 \text { kallikrein inhibitor units of } \\
\text { aprotinin }(0.2 \mathrm{ml} \mathrm{Trasslol}) \text {, immediately centrifuged and } \\
\text { plasma stored at }-20^{\circ} \mathrm{C} \text {. }\end{array}$ & $\begin{array}{l}\text { PIH } \\
3.51 \\
\pm 0.39\end{array}$ & $\begin{array}{l}\text { Pre- } \\
\text { eclampsia } \\
4.58 \\
\pm 0.46\end{array}$ & $\begin{array}{l}\text { Pregnant } \\
3.75 \\
\pm 0.20\end{array}$ & \\
\hline & & Kisspeptin serum levels in 981 & & Abortic & collection & & \\
\hline & {$[81$} & $\begin{array}{l}\text { pregnant women }(5.9 \text { to } 22.1 \\
\text { weeks) during the antenatal } \\
\text { booking visit. }\end{array}$ & 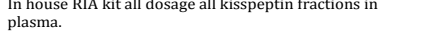 & & & & $\begin{array}{l}2.93 \\
\pm 1.36\end{array}$ \\
\hline & & $\begin{array}{l}\text { Kisspeptin serum and urinary } \\
\text { levels in } 49 \text { pregnant women }\end{array}$ & $\begin{array}{l}\text { In house RIA kit all kisspeptins. Blood collected in lithium } \\
\text { heparin tubes (plasma) and urine collected from all }\end{array}$ & $\begin{array}{l}\text { Plasma, } 3^{\text {rd }} \\
\text { Trimester }\end{array}$ & $\begin{array}{l}\text { Plasma, non- } \\
\text { pregnant }\end{array}$ & $\begin{array}{l}\text { Urine, } 3^{\text {rd }} \\
\text { Trimester }\end{array}$ & $\begin{array}{l}\text { Urine, non- } \\
\text { pregnant }\end{array}$ \\
\hline & & & $\begin{array}{l}\text { subjects in sterile containers. Samples were conserved } \\
\text { with } 5000 \text { kallikrein inhibitor units of aprotinin, stored at } \\
-20^{\circ} \mathrm{C} \text { and kisspeptin extraction before dosage. }\end{array}$ & $\begin{array}{l}17.95 \\
\pm 1.13\end{array}$ & $\begin{array}{l}0.08 \\
\pm 0.02\end{array}$ & $\begin{array}{l}0,39 \\
\pm 0.08\end{array}$ & $\begin{array}{l}0.10 \\
\pm 0.02\end{array}$ \\
\hline & $\begin{array}{l}\text { Anne Armstrong } \\
\text { et al. [82]* }\end{array}$ & $\begin{array}{l}\text { Kisspeptin levels in pregnant } \\
\text { women (317) (16-20 weeks) and } \\
\text { women with pre-eclampsia (57) } \\
\text { or growth restriction (118). }\end{array}$ & $\begin{array}{l}\text { In house ELISA kp-10. Antibody from Phoenix } \\
\text { Pharmaceuticals Inc, USA. Samples stored at }-70^{\circ} \mathrm{C} \text {. }\end{array}$ & $\begin{array}{l}\text { Pre- } \\
\text { eclampsia* } \\
1.11 \\
(0.60-1.9)\end{array}$ & $\begin{array}{l}\text { Growth } \\
\text { restriction* } \\
1.16 \\
(0.44-3.9)\end{array}$ & $\begin{array}{l}\quad \text { Normal } \\
1.19 \\
(0.49-2.30)\end{array}$ & I gestation* \\
\hline & Logie et al. [95] & $\begin{array}{l}\text { Kisspeptin levels in obese } \\
\text { pregnant women. }\end{array}$ & $\begin{array}{l}\text { ELISA kit kp-10 (Phoenix Pharmaceuticals Inc., Germany.) } \\
\text { Blood collected in EDTA tube between } 8 \text { and } 9 \text { am, } \\
\text { centrifuged } 1500 \mathrm{~g}, 10 \text { min at } 4^{\circ} \mathrm{C} \text {, plasma dosage. }\end{array}$ & $\begin{array}{l}\text { Geral } 16 \mathrm{w} \\
1.36 \\
\pm 0.81\end{array}$ & $\begin{array}{l}\text { Geral } 28 \mathrm{w} \\
2.23 \\
\pm 1.70\end{array}$ & $\begin{array}{l}\text { Geral } 36 \mathrm{w} \\
3.18 \\
\pm 2.77\end{array}$ & \\
\hline
\end{tabular}

a fast degradation rate that requires immediate blood processing after sampling [57, 97]. Chan et al. [60] added kisspeptin-10 in human plasma, incubated at $37^{\circ} \mathrm{C}$ and measure in different times by mass spectroscopy. Kisspeptin was undetectable in samples incubated for more than $60 \mathrm{~min}$. Similar result was observed after kisspeptin-10 intravenous or subcutaneous bolus administration in men and women. In healthy men was noticed a peak of kisspeptin 10 min after injection and undetectable levels after 50 min the same was observed that intravenous kp-10 or kp-54 in healthy women during the follicular phase [58].

Because these data suggest that kisspeptin has a short half-life in vivo and in vitro, some studies used aprotinin as an inhibitor to kallikrein (a kind of protease) [80, 93]. Other technique used is sample centrifugation at $4^{\circ} \mathrm{C}$ immediately after blood collection and plasma or serum at storage $-80^{\circ} \mathrm{C}[79,97]$.

Another parameter that should be considered is the circadian control of female reproduction. Some studies describe morning collection; however any study considered the kisspeptin dosage in different moments in the same volunteer. All these aspects show that is necessary a standardization in all steps (collect, pre-analytic and analytic process).

\section{Genetic Diversity of KISS1 and GPR54}


Inactivating and activating mutations in KISS1 and GPR54 genes are associated with infertility due to isolated hypogonadotropic hypogonadism (IHH) and central precocious puberty (CPP) (Table 2, Fig. 4) [57, 98, 99]. A man with IHH due to a homozygous insertion of a cytosine after nucleotide position 1001 (1001_1002insC) resulted in elongation of GPR54 protein from 398 to 441 amino acids. After treatment with pulsatile GnRH therapy for 2 years, he had a healthy son following an IVF procedure [31].

GPR54 mutations were showed in a Saudi-Arabian family carrying homozygous single nucleotide variant $443 \mathrm{~T}>\mathrm{C}$ in exon 3 , which resulted in a substitution a serine by leucine at position 148 of protein (L148S). Four homozygous male members received treatment and resulted in testicular maturation, spermatogenesis, ejaculation, and subsequent fertility [32]. In the same family, pulsatile GnRH treatment followed by exogenous gonadotropin therapy in an affected woman resulted in fertility restoration. She had two healthy kids after two unsuccessful pregnanices [32].

A homozygous mutation in exon 2 of GPR54 305T $>C$ results in a proline substitution for leucine at 102 position of GPR54 (NCBI reference sequence NM_032551.4(KISS1R): c.305T $>$ C). This mutation leads to IHH in two families from Arab-Muslim and Syria with

Table 2. Variants of KISS1 and GPR54 in different populations related with hypogonadotropic hypogonadism and central precocious puberty. ${ }^{*}$ Variants described as results articles and confirmed at ClinVar. ${ }^{* *}$ Study developed in France, but there was not information about family ethnicity. $\diamond$ Variants did not found at ClinVar. "Clinvar cited this variant as NM_002256.3(KISS1):c.339C >G (p.Asn113Lys). ${ }^{\dagger}$ Clinvar cited this variant as NM_002256.3(KISS1):c.220C >T (p.Pro74Ser). nIHH - normosmic isolated hypogonadotropic hypogonadism was defined as an absence of spontaneous pubertal maturation, inappropriately normal or low gonadotropin levels together with prepubertal or low testosterone or estradiol levels for age, absence of other pituitary hormonal deficiencies, no evidence of a hypothalamic-pituitary anatomical lesion on imaging and olfactory bulbs were normal $[29,101]$. KS - Kallmann's syndrome defined as an idiopathic hypogonadotropic hypogonadism with anosmia [100]. CDP - constitutional delay of puberty was defined by lack of breast development by the age of 13 years in girls and lack of testicular enlargement in boys by the age of 14 years [101]. CPP - central precocious puberty was defined as the development of secondary sexual characteristics before the age of 8 years in girls and 9 years in boys which results from premature activation of the hypothalamic-pituitary-gonadal axis, and gonadotropin independent precocious puberty [105]

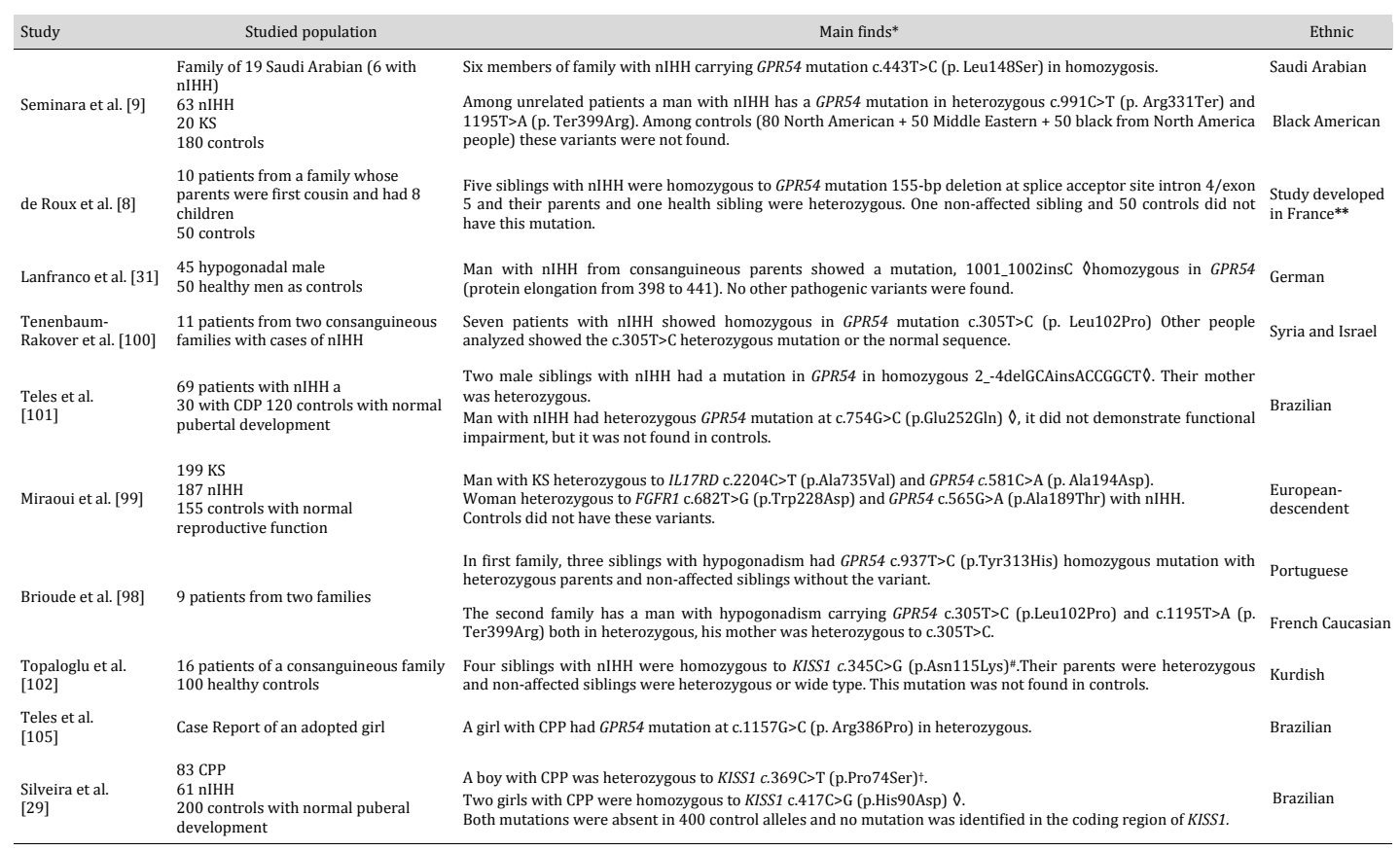


Fig. 4. Alignment of mutations in GPR54. Hypogonadotropic hypogonadism as consequence of inactivating mutations (circle) and central precocious puberty caused by activating mutations (rhombus). An insertion was represented by a red arrow and a black arrow represented a substitution of a stop codon at residue 399 to an arginine (1195T>A p.X399R).

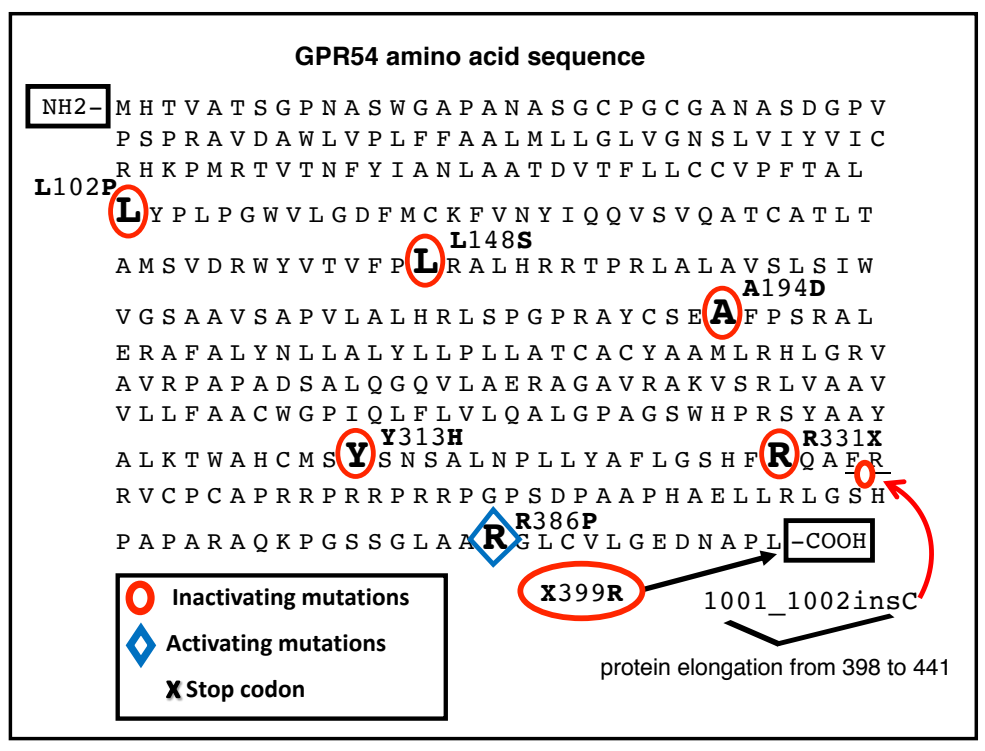

consanguineous history. Features observed among affected people were: low LH and FSH levels in both sex, primary amenorrhea in women and men with puberty delay (some of them had micropenis and bilateral cryptorchidism). All health relatives tested showed the T305C heterozygous mutation or normal sequence [100].

A homozygous GPR54 gene mutation was identified in two Brazilian siblings with normosmic isolated hypogonadotropic hypogonadism (nIHH). This mutation is characterized by deletion of three nucleotides at position -2 to -4 and insertion of seven nucleotides (IVS2 -2 -4delGCAinsACCGGCT) within the 3' splice acceptor site of intron 2. Computational analysis suggested this variant leads to a truncated receptor. Both boys had micropenis and cryptorchidism at birth and exhibited prepubertal testosterone levels associated with low basal gonadotropin. Their mother carried the same mutation in heterozygous form and had normal pubertal development [101].

Mutations in KISS1 gene also cause IHH. In a large consanguineous family, a change from cytosine to guanine 345C $>\mathrm{G}$ (NCBI reference sequence NM_002256.3:c.345C $\rightarrow$ G) resulted in a substitution of asparagine by lysine at residue 115 (N115K) in kisspeptin. This region is highly functionally conserved across species such as human, macaque, sheep, mouse, frog and zebrafish. The functional study revealed GPR54 had significantly reduced sensitivity to the mutant kisspeptin protein which was unable to achieve maximal inositol phosphate response [102]. In this family, four women with IHH were all homozygous for the mutation. Their unaffected relatives were wild type homozygous or heterozygous; therefore, this phenotype was considered transmitted as an autosomal recessive trait [102].

These studies showed the role of inactivating mutations in GPR54 in development of IHH. Animal models reproduce these results as demonstrated in mice with Gpr54 null mutation that were infertile, have low FSH and LH levels in male and female models [103].

Activating mutations in KISS1/GPR54 were observed in cases of central precocious puberty (CPP). A mutation in exon 3 of KISS1 gene caused CPP in a boy, the variant changed a cytosine to thymine at 369 (369C $>\mathrm{T})$ resulting in substitution of proline by serine at position 74 of primary kisspeptin (P74S). Ovarian cell cultures showed that mutated cells (P74S) incubated in 50\% human serum had less kisspeptin degradation than wild type, suggesting this mutation increased the time of kisspeptin activity [29].

A GPR54 mutation $1157 \mathrm{C}>\mathrm{G}$ in exon 5 showed an autosomal dominant trait. It replaced a proline by arginine at codon 386 (R386P) in the carboxy-terminal tail of the receptor and was identified in an adopted girl with CCP. The functional analysis of R386P in COS-7 reveled wild and mutated type cells internalized the GPR54 upon stimulation, but the most part was recycled back to the cell membrane. There were not differences between wild and 
mutated types in affinity of kisspeptin, or levels of receptor expression. R386P did not affect the GPR54 trafficking. Nevertheless, this mutation prolongs kisspeptin response decreasing GPR54 degradation, consequently increasing the number of receptors recycled back to the plasma membrane that could justify the phenotype associated with this mutation $[14,104$, 105].

Even though there are many variants related to hypogonadism and precocious puberty, there is still no evidence of variants associated with assisted reproduction outcomes.

\section{Conclusion}

Kisspeptins are essential to puberty development and participate in many events in woman reproduction such as LH peak, implantation, and pregnancy. There is evidence that kisspeptin could induce the oocyte maturation during the controlled ovarian hyperstimulation; however, there is not a consensus about route of administration. Also, there is a lack of evidence about KISS1 and GPR54 variants influence in assisted reproduction treatments. Kisspeptin dosage data are limited and the results are not clear, due to different methods and lack of knowledge of pre-analytical methods. The role of kisspeptin in reproduction function is incontestable; nevertheless, more experimental studies and clinical trials are needed to explore the role of kisspeptin in assisted reproduction treatments.

\section{Acknowledgements}

The authors thank CAPES for granting Camila Martins Trevisan a Ph.D scholarship. This work was supported by FAPESP research grant number 2016/25953-9.

All authors contributed to the identification and critical evaluation of the relevant literature and to drafting the manuscript, as well as to approve the final version of the manuscript. B.B. and C.P.B. conceived the theme and prepared the proposal. C.P.B. and R.O. contributed clinical and scientific expertise as gynecologists. E.M. contributed expertise in biochemistry and physiology. B.B., D.M.C. and K.C. contributed expertise in genetics and molecular biology. C.M.T was involved in all stages of the research.

\section{Disclosure Statement}

The authors have no conflicts of interest to disclose.

\section{References}

1 Lee JH, Miele ME, Hicks DJ, Phillips KK, Trent JM, Weissman BE, Welch DR: KiSS-1, a Novel Human Malignant Melanoma Metastasis-suppressor Gene. J Natl Cancer Inst 1996;88:1731-1737.

-2 Lee DK, Nguyen T, O’Neill GP, Cheng R, Liu Y, Howard AD, Coulombe N, Tan CP, Tang-Nguyen AT, George SR, O'Dowd BF: Discovery of a receptor related to the galanin receptors. FEBS Lett 1999;446:103-107.

-3 Kotani M, Detheux M, Vandenbogaerde A, Communi D, Vanderwinden JM, Le Poul E, Brézillon S, Tyldesley R, Suarez-Huerta N, Vandeput F, Blanpain C, Schiffmann SN, Vassart G, Parmentier M: The Metastasis Suppressor Gene KiSS-1 Encodes Kisspeptins, the Natural Ligands of the Orphan G Protein-coupled Receptor GPR54. J Biol Chem 2001;276:34631-34636.

4 Muir AI, Chamberlain L, Elshourbagy NA, Michalovich D, Moore DJ, Calamari A, Szekeres PG, Sarau HM, Chambers JK, Murdock P, Steplewski K, Shabon U, Miller JE, Middleton SE, Darker JG, Larminie CG, Wilson S, Bergsma DJ, Emson P, Faull R, et al.: AXOR12, a Novel Human G Protein-coupled Receptor, Activated by the Peptide KiSS-1. J Biol Chem 2001;276:28969-28975.

5 Ohtaki T, Shintani Y, Honda SIS, Matsumoto H, Hori A, Kanehashi K, Terao Y, Kumano S, Takatsu Y, Masuda Y, 


\section{Cellular Physiology Cell Physiol Biochem 2018;49:1259-1276 \begin{tabular}{l|l|l} 
and Biochemistry Published online: 12 September, 2018 & $\begin{array}{l}\text { (c) } 2018 \text { The Author(s). Published by S. Karger AG, Basel } \\
\text { www.karger.com/cpb }\end{array}$
\end{tabular}

Ishibashi Y, Watanabe T, Asada M, Yamada T, Suenaga M, Kitada C, Usuki S, Kurokawa T, Onda H, Nishimura 0 , et al.: Metastasis suppressor gene Kiss-1 encodes peptide ligand of a G-protein-coupled receptor. Nature 2001;411:613-617.

6 Mead E, Maguire J, Kuc R, Davenport A, Votsi E, Roussos D: Kisspeptins: a multifunctional peptide system with a role in reproduction, cancer and the cardiovascular system. Br J Pharmacol 2007;151:1143-1153.

7 Richard N, Galmiche G, Corvaisier S, Caraty A, Kottler M-L: KiSS-1 and GPR54 Genes are Co-Expressed in Rat Gonadotrophs and Differentially Regulated In vivo by Oestradiol and Gonadotrophin-Releasing Hormone. J Neuroendocrinol 2008;20:381-393.

$\checkmark 8$ de Roux N, Genin E, Carel J-C, Matsuda F, Chaussain J-L, Milgrom E: Hypogonadotropic hypogonadism due to loss of function of the KiSS1-derived peptide receptor GPR54 Proc Natl Acad Sci 2003;100:1097210976.

-9 Seminara SB, Messager S, Chatzidaki EE, Thresher RR, Acierno JS, Shagoury JK, Bo-Abbas Y, Kuohung W, Schwinof KM, Hendrick AG, Zahn D, Dixon J, Kaiser UB, Slaugenhaupt SA, Gusella JF, O’Rahilly S, Carlton MB, Crowley WF Jr, Aparicio SA, Colledge WH: The GPR54 Gene as a Regulator of Puberty. N Engl J Med 2003;349:1614-1627.

10 de Roux N: GnRH receptor and GPR54 inactivation in isolated gonadotropic deficiency. Best Pract Res Clin Endocrinol Metab 2006;20:515-528.

11 Tena-Sempere M: KiSS-1 and reproduction: focus on its role in the metabolic regulation of fertility. Neuroendocrinology 2006;83:275-281.

12 Kanda S, Oka Y: Structure, synthesis, and phylogeny of kisspeptin and its receptor; in Kauffman AS, Smith JT (eds): Kisspeptin Signaling in Reproductive Biology. Adv Exp Med Bio, New York, Springer, 2013, vol 704, pp 9-26.

13 Pasquier J, Kamech N, Lafont AG, Vaudry H, Rousseau K, Dufour S: Molecular evolution of GPCRs: Kisspeptin/kisspeptin receptors. J Mol Endocrinol 2014;52:T101-117.

14 Bianco SDC, Kaiser UB: Molecular Biology of the Kisspeptin Receptor: Signaling, Function, and Mutations; in Kauffman AS, Smith JT (eds): Kisspeptin Signaling in Reproductive Biology. Adv Exp Med Bio, New York, Springer, 2013, vol 704, pp 133-158.

15 Evans BJ, Wang Z, Mobley LL, Khosravi D, Fujii N, Navenot JM, Peiper SC: Physical association of GPR54 C-terminal with protein phosphatase 2A. Biochem Biophys Res Commun 2008;377:1067-1071.

16 Dumalska I, Wu M, Morozova E, Liu R, van den Pol A, Alreja M: Excitatory Effects of the Puberty-Initiating Peptide Kisspeptin and Group I Metabotropic Glutamate Receptor Agonists Differentiate Two Distinct Subpopulations of Gonadotropin-Releasing Hormone Neurons. J Neurosci 2008;28:8003-8013.

17 Pielecka-Fortuna J, Moenter SM: Kisspeptin Increases $\gamma$-Aminobutyric Acidergic and Glutamatergic Transmission Directly to Gonadotropin-Releasing Hormone Neurons in an Estradiol-Dependent Manner. Endocrinology 2010;151:291-300.

18 Novaira HJ, Ng Y, Wolfe A, Radovick S: Kisspeptin increases GnRH mRNA expression and secretion in GnRH secreting neuronal cell lines. Mol Cell Endocrinol 2009;311:126-134.

19 Novaira HJ, Sonko ML, Radovick S: Kisspeptin Induces Dynamic Chromatin Modifications to Control GnRH Gene Expression. Mol Neurobiol 2016;53:3315-3325.

20 d'Anglemont de Tassigny X, Ackroyd KJ, Chatzidaki EE, Colledge WH: Kisspeptin Signaling Is Required for Peripheral But Not Central Stimulation of Gonadotropin-Releasing Hormone Neurons by NMDA. J Neurosci 2010;30:8581-8590.

21 Oakley AE, Clifton DK, Steiner RA: Kisspeptin signaling in the brain. Endocr Rev 2009;30:713-743.

22 Gaytan F, Garcia-Galiano D, Dorfman MD, Manfredi-Lozano M, Castellano JM, Dissen GA, Ojeda SR, TenaSempere M: Kisspeptin receptor haplo-insufficiency causes premature ovarian failure despite preserved gonadotropin secretion. Endocrinology 2014;155:3088-3097.

23 Navarro VM, Fernández-Fernández R, Castellano JM, Roa J, Mayen A, Barreiro ML, Gaytan F, Aguilar E, Pinilla L, Dieguez C, Tena-Sempere M: Advanced vaginal opening and precocious activation of the reproductive axis by KiSS-1 peptide, the endogenous ligand of GPR54. J Physiol 2004;561:379-386.

24 Shahab M, Mastronardi C, Seminara SB, Crowley WF, Ojeda SR, Plant TM: Increased hypothalamic GPR54 signaling: a potential mechanism for initiation of puberty in primates. Proc Natl Acad Sci U S A 2005;102:2129-2134.

-25 Plant TM, Ramaswamy S, DiPietro MJ: Repetitive Activation of Hypothalamic G Protein-Coupled Receptor 


\section{Cellular Physiology Cell Physiol Biochem 2018;49:1259-1276 \begin{tabular}{l|l|l} 
and Biochemistry Published online: 12 September, 2018 & $\begin{array}{l}\text { (c) } 2018 \text { The Author(s). Published by S. Karger AG, Basel } \\
\text { www.karger.com/cpb }\end{array}$
\end{tabular}

54 with Intravenous Pulses of Kisspeptin in the Juvenile Monkey ( Macaca mulatta) Elicits a Sustained Train of Gonadotropin-Releasing Hormone Discharges. Endocrinology 2006;147:1007-1013.

-26 Özgen İT, Torun E, Bayraktar-Tanyeri B, Durmaz E, Kılıç E, Cesur Y: The relation of urinary bisphenol A with kisspeptin in girls diagnosed with central precocious puberty and premature thelarche. J Pediatr Endocrinol Metab 2016;29:337-341.

27 Chen CY, Chou YY, Wu YM, Lin CC, Lin SJ, Lee CC: Phthalates may promote female puberty by increasing kisspeptin activity. Hum Reprod 2013;28:2765-2773.

-28 Seminara SB, DiPietro MJ, Ramaswamy S, Crowley WF, Plant TM: Continuous human metastin 45-54 infusion desensitizes G protein-coupled receptor 54-induced gonadotropin-releasing hormone release monitored indirectly in the juvenile male rhesus monkey (Macaca mulatta): A finding with therapeutic implications. Endocrinology 2006;147:2122-2126.

29 Silveira LG, Noel SD, Silveira-Neto AP, Abreu AP, Brito VN, Santos MG, Bianco SD, Kuohung W, Xu S, Gryngarten M, Escobar ME, Arnhold IJ, Mendonca BB, Kaiser UB, Latronico AC: Mutations of the KISS1 gene in disorders of puberty. J Clin Endocrinol Metab 2010;95:2276-2280.

-30 Chan YM, Broder-Fingert S, Seminara SB: Reproductive functions of kisspeptin and Gpr54 across the life cycle of mice and men. Peptides 2009;30:42-48.

31 Lanfranco F, Gromoll J, von Eckardstein S, Herding EM, Nieschlag E, Simoni M: Role of sequence variations of the GnRH receptor and G protein-coupled receptor 54 gene in male idiopathic hypogonadotropic hypogonadism. Eur J Endocrinol 2005;153:845-852.

-32 Pallais JC, Bo-Abbas Y, Pitteloud N, Crowley WF, Seminara SB: Neuroendocrine, gonadal, placental, and obstetric phenotypes in patients with IHH and mutations in the G-protein coupled receptor, GPR54. Mol Cell Endocrinol 2006;25:70-77.

-33 Pinto FM, Cejudo-Román A, Ravina CG, Fernández-Sánchez M, Martín-Lozano D, Illanes M, Tena-Sempere M, Candenas ML: Characterization of the kisspeptin system in human spermatozoa. Int J Androl 2012;35:6373.

34 Ramzan MH, Ramzan M, Ramzan F, Wahab F, Jillani M, Khan MA, Shah M: Insight into the serum kisspeptin levels in infertile males. Arch Iran Med 2015;18:12-17.

-35 Kotani M, Katagiri F, Hirai T, Kagawa J: Plasma kisspeptin levels in male cases with hypogonadism. Endocr J 2014;61:1137-1140.

-36 Kinoshita M, Tsukamura H, Adachi S, Matsui H, Uenoyama Y, Iwata K, Yamada S, Inoue K, Ohtaki T, Matsumoto H, Maeda K: Involvement of Central Metastin in the Regulation of Preovulatory Luteinizing Hormone Surge and Estrous Cyclicity in Female Rats. Endocrinology 2005;146:4431-4436.

37 Smith JT, Popa SM, Clifton DK, Hoffman GE, Steiner RA: Kiss1 Neurons in the Forebrain as Central Processors for Generating the Preovulatory Luteinizing Hormone Surge. J Neurosci 2006;26:6687-6694.

-38 Clarkson J, d'Anglemont de Tassigny X, Moreno AS, Colledge WH, Herbison AE: Kisspeptin-GPR54 Signaling Is Essential for Preovulatory Gonadotropin-Releasing Hormone Neuron Activation and the Luteinizing Hormone Surge. J Neurosci 2008;28:8691-8697.

39 Meczekalski B, Katulski K, Podfigurna-Stopa A, Czyzyk A, Genazzani AD: The spontaneous endogenous pulsatile release of kisspeptin is temporally coupled with luteinizing hormone in healthy women. Fertil Steril 2016;105:1345-1350e2.

$>40$ Hrabovszky E, Ciofi P, Vida B, Horvath MC, Keller E, Caraty A, Bloom SR, Ghatei MA, Dhillo WS, Liposits Z, Kallo I: The kisspeptin system of the human hypothalamus: Sexual dimorphism and relationship with gonadotropin-releasing hormone and neurokinin B neurons. Eur J Neurosci 2010;31:1984-1998.

41 Gottsch ML, Cunningham MJ, Smith JT, Popa SM, Acohido B V., Crowley WF, Seminara S, Clifton DK, Steiner RA: A Role for Kisspeptins in the Regulation of Gonadotropin Secretion in the Mouse. Endocrinology 2004;145:4073-4077.

42 Navarro VM, Castellano JM, Fernández-Fernández R, Tovar S, Roa J, Mayen A, Nogueiras R, Vazquez MJ, Barreiro ML, Magni P, Aguilar E, Dieguez C, Pinilla L, Tena-Sempere M: Characterization of the Potent Luteinizing Hormone-Releasing Activity of KiSS-1 Peptide, the Natural Ligand of GPR54. Endocrinology 2005;146:156-163.

-43 Han S-K, Gottsch ML, Lee KJ, Popa SM, Smith JT, Jakawich SK, Clifton DK, Steiner RA, Herbison AE: Activation of Gonadotropin-Releasing Hormone Neurons by Kisspeptin as a Neuroendocrine Switch for the Onset of Puberty. J Neurosci 2005;25:11349-11356.

44 Irwig MS, Fraley GS, Smith JT, Acohido B V, Popa SM, Cunningham MJ, Gottsch ML, Clifton DK, Steiner RA: 


\section{Cellular Physiology Cell Physiol Biochem 2018;49:1259-1276 \begin{tabular}{ll|l} 
and Biochemistry Published online: 12 September, 2018 & $\begin{array}{l}\text { (c) } 2018 \text { The Author(s). Published by S. Karger AG, Basel } \\
\text { www.karger.com/cpb }\end{array}$ \\
\hline
\end{tabular}

Kisspeptin activation of gonadotropin releasing hormone neurons and regulation of KiSS-1 mRNA in the male rat. Neuroendocrinology 2004;80:264-272.

45 Messager S, Chatzidaki EE, Ma D, Hendrick AG, Zahn D, Dixon J, Thresher RR, Malinge I, Lomet D, Carlton MB, Colledge WH, Caraty A, Aparicio SA: Kisspeptin directly stimulates gonadotropin-releasing hormone release via G protein-coupled receptor 54. Proc Natl Acad Sci U S A 2005;102:1761-1766.

46 Smith JT, Shahab M, Pereira A, Pau KYF, Clarke IJ, Pau F, Clarke IJ: Hypothalamic expression of KISS1 and gonadotropin inhibitory hormone genes during the menstrual cycle of a non-human primate. Biol Reprod 2010;83:568-577.

47 Dhillo WS, Chaudhri OB, Patterson M, Thompson EL, Murphy KG, Badman MK, McGowan BM, Amber V, Patel S, Ghatei MA, Bloom SR: Kisspeptin-54 stimulates the hypothalamic-pituitary gonadal axis in human males. J Clin Endocrinol Metab 2005;90:6609-6615.

48 Narayanaswamy S, Jayasena CN, Ng N, Ratnasabapathy R, Prague JK, Papadopoulou D, Abbara A, Comninos AN, Bassett P, Bloom SR, Veldhuis JD, Dhillo WS: Subcutaneous infusion of kisspeptin-54 stimulates gonadotrophin release in women and the response correlates with basal oestradiol levels. Clin Endocrinol (Oxf) 2016;84:939-945.

49 Szawka RE, Ribeiro AB, Leite CM, Helena CV V, Franci CR, Anderson GM, Hoffman GE, Anselmo-Franci JA: Kisspeptin regulates prolactin release through hypothalamic dopaminergic neurons. Endocrinology 2010;151:3247-3257.

50 Revel FG, Saboureau M, Masson-Pévet M, Pévet P, Mikkelsen JD, Simonneaux V: Kisspeptin Mediates the Photoperiodic Control of Reproduction in Hamsters. Curr Biol 2006;16:1730-1735.

51 Herbison AE, Pape JR: New Evidence for Estrogen Receptors in Gonadotropin-Releasing Hormone Neurons. Front Neuroendocrinol 2001;22:292-308.

-52 Wintermantel TM, Campbell RE, Porteous R, Bock D, Gröne HJ, Todman MG, Korach KS, Greiner E, Pérez CA, Schütz G, Herbison AE: Definition of Estrogen Receptor Pathway Critical for Estrogen Positive Feedback to Gonadotropin-Releasing Hormone Neurons and Fertility. Neuron 2006;52:271-280.

53 Li D, Mitchell D, Luo J, Yi Z, Cho S-GG, Guo J, Li X, Ning G, Wu X, Liu M: Estrogen Regulates KiSS1 Gene Expression through Estrogen Receptor $\alpha$ and SP Protein Complexes. Endocrinology 2007;148:4821-4828.

54 Latif R, Rafique N: Serum kisspeptin levels across different phases of the menstrual cycle and their correlation with serum oestradiol. Neth J Med 2015;73:175-178.

55 Zhai J, Ding L, Zhao S, Li W, Sun Y, Su S, Zhang J, Zhao H, Chen ZJ: Kisspeptin: a new marker for human preovulation. Gynecol Endocrinol 2017;33:560-563.

56 García-Ortega J, Pinto FM, Fernández-Sánchez M, Prados N, Cejudo-Román A, Almeida TA, Hernández M, Romero M, Tena-Sempere M, Candenas L: Expression of neurokinin B/NK3 receptor and kisspeptin/KISS1 receptor in human granulosa cells. Hum Reprod 2014;29:2736-2746.

57 Chan YM: Effects of Kisspeptin on Hormone Secretion in Humans; in Kauffman AS, Smith JT (eds): Kisspeptin Signaling in Reproductive Biology. Adv Exp Med Bio, New York, Springer, 2013, vol 704, pp 89-112.

58 Jayasena CN, Nijher GMK, Comninos AN, Abbara A, Januszewki A, Vaal ML, Sriskandarajah L, Murphy KG, Farzad Z, Ghatei MA, Bloom SR, Dhillo WS: The effects of kisspeptin-10 on reproductive hormone release show sexual dimorphism in humans. J Clin Endocrinol Metab 2011;96:1963-1972.

59 Dhillo WS, Chaudhri OB, Thompson EL, Murphy KG, Patterson M, Ramachandran R, Nijher GK, Amber V, Kokkinos A, Donaldson M, Ghatei MA, Bloom SR: Kisspeptin-54 stimulates gonadotropin release most potently during the preovulatory phase of the menstrual cycle in women. J Clin Endocrinol Metab 2007;92:3958-3966.

60 Chan Y-MM, Butler JP, Pinnell NE, Pralong FP, Crowley WF, Ren C, Chan KK, Seminara SB: Kisspeptin resets the hypothalamic GnRH clock in men. J Clin Endocrinol Metab 2011;96:908-915.

61 Chan YM, Butler JP, Sidhoum VF, Pinnell NE, Seminara SB: Kisspeptin administration to women: A window into endogenous kisspeptin secretion and GnRH responsiveness across the menstrual cycle. J Clin Endocrinol Metab 2012;97:1458-1467.

62 Jayasena CN, Abbara A, Narayanaswamy S, Comninos AN, Ratnasabapathy R, Bassett P, Mogford JT, Malik Z, Calley J, Ghatei MA, Bloom SR, Dhillo WS: Direct comparison of the effects of intravenous kisspeptin-10, kisspeptin-54 and GnRH on gonadotrophin secretion in healthy men. Hum Reprod 2015;30:1934-1941.

-63 Altmäe S, Hovatta O, Stavreus-Evers A, Salumets A: Genetic predictors of controlled ovarian 


\section{Cellular Physiology Cell Physiol Biochem 2018;49:1259-1276 \begin{tabular}{l|l|l} 
and Biochemistry Published online: 12 September, 2018 & $\begin{array}{l}\text { (c) } 2018 \text { The Author(s). Published by S. Karger AG, Basel } \\
\text { www.karger.com/cpb }\end{array}$
\end{tabular}

hyperstimulation: Where do we stand today? Hum Reprod Update 2011;17:813-828.

64 Cejudo Roman A, Pinto FM, Dorta I, Almeida TA, Hernández M, Illanes M, Tena-Sempere M, Candenas L: Analysis of the expression of neurokinin B, kisspeptin, and their cognate receptors NK3R and KISS1R in the human female genital tract. Fertil Steril 2012;97:1213-1219.

65 George J, Quinton R, Young J, Veldhuis J, Millar R, Anderson R: Functional characterisation and translational clinical applications of kisspeptin-10. Endocrine Abstracts 2012;28:0C1.1.

-66 Matsuzaki T, Tungalagsuvd A, Takeshi I, Munkhzaya M, Yanagihara R, Tokui T, Yano K, Mayila Y, Kato T, Kuwahara A, Matsui S, Irahara M: Kisspeptin mRNA expression is increased in the posterior hypothalamus in the rat model of polycystic ovary syndrome. Endocr J 2017;64:7-14.

67 Albalawi FS, Daghestani MH, Daghestani MH, Eldali A, Warsy AS: rs4889 polymorphism in KISS1 gene, its effect on polycystic ovary syndrome development and anthropometric and hormonal parameters in Saudi women. J Biomed Sci 2018;25:50.

68 Gearhart J, Coutifaris C: In vitro fertilization, the nobel prize, and human embryonic stem cells. Cell Stem Cell 2011;8:12-15.

69 Golan A, Ron-el R, Herman A, Soffer Y, Weinraub Z, Caspi E: Ovarian hyperstimulation syndrome: an update review. Obstet Gynecol Surv 1989;44:430-440.

70 Mansour R, Ishihara O, Adamson GD, Dyer S, de Mouzon J, Nygren KG, Sullivan E, Zegers-Hochschild F: International Committee for Monitoring Assisted Reproductive Technologies world report: Assisted Reproductive Technology 2006. Hum Reprod 2014;29:1536-1551.

71 Abbara A, Jayasena CN, Christopoulos G, Narayanaswamy S, Izzi-Engbeaya C, Nijher GM, Comninos AN, Peters D, Buckley A, Ratnasabapathy R, Prague JK, Salim R, Lavery SA, Bloom SR, Szigeti M, Ashby DA, Trew GH1, Dhillo WS: Efficacy of kisspeptin-54 to trigger Oocyte maturation in women at high risk of ovarian hyperstimulation syndrome (OHSS) during in vitro fertilization (IVF) therapy. J Clin Endocrinol Metab 2015;100:3322-3331.

-72 Jayasena CN, Abbara A, Comninos AN, Nijher GMK, Christopoulos G, Narayanaswamy S, Izzi-Engbeaya C, Sridharan M, Mason AJ, Warwick J, Ashby D, Ghatei MA, Bloom SR, Carby A, Trew GH, Dhillo WS: Kisspeptin-54 triggers egg maturation in women undergoing in vitro fertilization. J Clin Invest 2014;124:3667-3677.

73 Abbara A, Clarke S, Islam R, Prague JK, Comninos AN, Narayanaswamy S, Papadopoulou D, Roberts R, IzziEngbeaya C, Ratnasabapathy R, Nesbitt A, Vimalesvaran S, Salim R, Lavery SA, Bloom SR, Huson L, Trew GH, Dhillo WS: A second dose of kisspeptin-54 improves oocyte maturation in women at high risk of ovarian hyperstimulation syndrome: a Phase 2 randomized controlled trial. Hum Reprod 2017;32:1915-1924.

-74 De Pedro MA, Morán J, Díaz I, Murias L, Fernández-Plaza C, González C, Díaz E: Circadian Kisspeptin expression in human term placenta. Placenta 2015;36:1337-1339.

75 Bilban M, Ghaffari-Tabrizi N, Hintermann E, Bauer S, Molzer S, Zoratti C, Malli R, Sharabi A, Hiden U, Graier W, Knöfler M, Andreae F, Wagner O, Quaranta V, Desoye G: Kisspeptin-10, a KiSS-1/metastinderived decapeptide, is a physiological invasion inhibitor of primary human trophoblasts. J Cell Sci 2004;117:1319-1328.

76 Schäfer-Somi S, Ay S, Kaya D, Sözmen M, Beceriklisoy H, Ağaoğlu A, Fındık M, Van Haeften T, Aslan S: Kisspeptin-10 and the G protein-coupled receptor 54 are differentially expressed in the canine pregnant uterus and trophoblast cells. Reprod Domest Anim 2016;10:1-7.

-77 Fayazi M, Calder M, Bhattacharya M, Vilos GA, Power S, Babwah AV: The pregnant mouse uterus exhibits a functional kisspeptin/KISS1R signaling system on the day of embryo implantation. Reprod Biol Endocrinol 2015;13:105.

78 Calder M, Chan YM, Raj R, Pampillo M, Elbert A, Noonan M, Gillio-Meina C, Caligioni C, Bérubé NG, Bhattacharya M, Watson AJ, Seminara SB, Babwah AV: Implantation failure in female Kiss1-/- mice is independent of their hypogonadic state and can be partially rescued by leukemia inhibitory factor. Endocrinology 2014;155:3065-3078.

-79 Horikoshi Y, Matsumoto H, Takatsu Y, Ohtaki T, Kitada C, Usuki S, Fujino M: Dramatic elevation of plasma metastin concentrations in human pregnancy: Metastin as a novel placenta-derived hormone in humans. J Clin Endocrinol Metab 2003;88:914-919.

-80 Jayasena CN, Comninos AN, Narayanaswamy S, Abbara A, Nijher GMK, Cheema M, Malik Z, Ghatei 


\section{Cellular Physiology Cell Physiol Biochem 2018;49:1259-1276 \begin{tabular}{ll|l} 
and Biochemistry Published online: 12 September, 2018 & $\begin{array}{l}\text { (c) } 2018 \text { The Author(s). Published by S. Karger AG, Basel } \\
\text { www.karger.com/cpb }\end{array}$ \\
\hline
\end{tabular}

MA, Bloom SR, Dhillo WS: The identification of elevated urinary kisspeptin-immunoreactivity during pregnancy. Ann Clin Biochem 2015;52:395-398.

-81 Jayasena CN, Abbara A, Izzi-Engbeaya C, Comninos AN, Harvey RA, Gonzalez Maffe J, Sarang Z, Ganiyu-Dada Z, Padilha AI, Dhanjal M, Williamson C, Regan L, Ghatei MA, Bloom SR, Dhillo WS: Reduced levels of plasma kisspeptin during the antenatal booking visit are associated with increased risk of miscarriage. J Clin Endocrinol Metab 2014;99:E2652-2660.

82 Anne Armstrong R, Reynolds RM, Leask R, Shearing CH, Calder AA, Riley SC: Decreased serum levels of kisspeptin in early pregnancy are associated with intra-uterine growth restriction and pre-eclampsia. Prenat Diagn 2009;29:982-985.

83 Matjila M, Millar R, Van Der Spuy Z, Katz A: Elevated placental expression at the maternal-fetal interface but diminished maternal circulatory kisspeptin in preeclamptic pregnancies. Pregnancy Hypertens 2016;6:79-87.

-84 Reichetzeder C, Dwi Putra SE, Li J, Hocher B: Developmental Origins of Disease - Crisis Precipitates Change. Cell Physiol Biochem 2016;39:919-938.

-85 Li J, Tsuprykov 0, Yang X, Hocher B: Paternal programming of offspring cardiometabolic diseases in later life. J Hypertens 2016;34:2111-2126.

-86 Lu Y-P, Reichetzeder C, Prehn C, Yin L-H, Yun C, Zeng S, Chu C, Adamski J, Hocher B: Cord Blood Lysophosphatidylcholine 16:1 is Positively Associated with Birth Weight. Cell Physiol Biochem 2018;45:614-624.

-87 Jamil Z, Fatima SS, Arif S, Alam F, Rehman R: Kisspeptin and embryo implantation after ICSI. Reprod Biomed Online 2017;34:147-153.

-88 Mumtaz A, Khalid A, Jamil Z, Fatima SS, Arif S, Rehman R: Kisspeptin: A potential factor for unexplained infertility and impaired embryo implantation. Int J Fertil Steril 2017;11:99-104.

-89 Curtis AE, Murphy KG, Chaudhri OB, Ramachandran R, Young A-M, Waxman J, Nijher GM, Bewick GA, Ghatei MA, Bloom SR, Dhillo WS: Kisspeptin is released from human prostate cancer cell lines but plasma kisspeptin is not elevated in patients with prostate cancer. Oncol Rep 2010;23:1729-1734.

$\$ 90$ Canbay E, Ergen A, Bugra D, Yamaner S, Eraltan IY, Buyukuncu Y, Bulut T: Kisspeptin-54 levels are increased in patients with colorectal cancer. World J Surg 2012;36:2218-2224.

-91 Bacopoulou F, Lambrou GI, Rodanaki ME, Stergioti E, Efthymiou V, Deligeoroglou E, Markantonis SI: Serum kisspeptin concentrations are negatively correlated with body mass index in adolescents with anorexia nervosa and amenorrhea. Hormones 2017;16:33-41.

-92 Chen X, Mo Y, Li L, Chen Y, Li Y, Yang D: Increased plasma metastin levels in adolescent women with polycystic ovary syndrome. Eur J Obstet Gynecol Reprod Biol 2010;149:72-76.

$\$ 93$ Nijher GMK, Chaudhri OB, Ramachandran R, Murphy KG, Zac-Varghese SEK, Fowler A, Chinthapalli K, Patterson M, Thompson EL, Williamson C, Kumar S, Ghatei MA, Bloom SR, Dhillo WS: The effects of kisspeptin-54 on blood pressure in humans and plasma kisspeptin concentrations in hypertensive diseases of pregnancy. Br J Clin Pharmacol 2010;70:674-681.

$\$ 94$ Andreozzi F, Mannino GC, Mancuso E, Spiga R, Perticone F, Sesti G: Plasma kisspeptin levels are associated with insulin secretion in nondiabetic individuals. PLoS One 2017;12:e0179834.

\$95 Logie JJ, Denison FC, Riley SC, Ramaesh T, Forbes S, Norman JE, Reynolds RM: Evaluation of kisspeptin levels in obese pregnancy as a biomarker for pre-eclampsia. Clin Endocrinol (Oxf) 2012;76:887-893.

-96 Rafique N, Latif R: Serum kisspeptin levels in normal and overweight Saudi females and its relation with anthropometric indices. Ann Saudi Med 2015;35:157-160.

$\$ 97$ Ramachandran R, Patterson M, Murphy KG, Dhillo WS, Patel S, Kazarian A, Ghatei MA, Bloom SR: Preanalytical factors affecting RIA measurement of plasma kisspeptin. Clin Chem 2008;54:615-617.

$\$ 98$ Brioude F, Bouligand J, Francou B, Fagart J, Roussel R, Viengchareun S, Combettes L, Brailly-Tabard S, Lombès M, Young J, Guiochon-Mantel A: Two Families with Normosmic Congenital Hypogonadotropic Hypogonadism and Biallelic Mutations in KISS1R (KISS1 Receptor): Clinical Evaluation and Molecular Characterization of a Novel Mutation. PLoS One 2013;8:e53896.

99 Miraoui H, Dwyer AA, Sykiotis GP, Plummer L, Chung W, Feng B, Beenken A, Clarke J, Pers TH, Dworzynski P, Keefe K, Niedziela M, Raivio T, Crowley WF Jr, Seminara SB, Quinton R, Hughes VA, Kumanov P, Young J, Yialamas MA, et al.: Mutations in FGF17, IL17RD, DUSP6, SPRY4, and FLRT3 Are Identified in Individuals with Congenital Hypogonadotropic Hypogonadism. Am J Hum Genet 2013;92:725-743.

100 Tenenbaum-Rakover Y, Commenges-Ducos M, Iovane AA, Aumas C, Admoni O, de Roux N: Neuroendocrine 


\section{Cellular Physiology Cell Physiol Biochem 2018;49:1259-1276 \begin{tabular}{ll|l} 
DOI: 10.1159/000493406 & $\begin{array}{l}\text { O 2018 The Author(s). Published by S. Karger AG, Basel } \\
\text { www.karger.com/cpb }\end{array}$ \\
\hline
\end{tabular} \\ Trevisan et al.: Insights into Kisspeptin/GPR54 System}

Phenotype Analysis in Five Patients with Isolated Hypogonadotropic Hypogonadism due to a L102P Inactivating Mutation of GPR54. J Clin Endocrinol Metab 2007;92:1137-1144.

101 Teles MG, Trarbach EB, Noel SD, Guerra G, Jorge A, Beneduzzi D, Bianco SD, Mukherjee A, Baptista MT, Costa EM, De Castro M, Mendonça BB, Kaiser UB, Latronico AC: A novel homozygous splice acceptor site mutation of KISS1R in two siblings with normosmic isolated hypogonadotropic hypogonadism. Eur J Endocrinol 2010;163:29-34.

$>102$ Topaloglu AK, Tello JA, Kotan LD, Ozbek MN, Yilmaz MB, Erdogan S, Gurbuz F, Temiz F, Millar RP, Yuksel B: Inactivating KISS1 Mutation and Hypogonadotropic Hypogonadism. N Engl J Med 2012;366:629-635.

103 Novaira HJ, Sonko ML, Hoffman G, Koo Y, Ko C, Wolfe A, Radovick S: Disrupted Kisspeptin Signaling in GnRH Neurons Leads to Hypogonadotrophic Hypogonadism. Mol Endocrinol 2014;28:225-238.

104 Bianco SDC, Vandepas L, Correa-Medina M, Gereben B, Mukherjee A, Kuohung W, Carroll R, Teles MG, Latronico AC, Kaiser UB: KISS1R intracellular trafficking and degradation: Effect of the Arg386Pro diseaseassociated mutation. Endocrinology 2011;152:1616-1626.

105 Teles MMG, Bianco SDCS, Nahime Brito V, Trarbarch EB, Kuohung W, Xu S, Seminara SB, Mendonça BB, Kaiser UB, Latronico AC: A GPR54 -Activating Mutation in a Patient with Central Precocious Puberty. N Engl J Med 2008;358:709-715.

106 SWISS-MODEL: Q969F8 (KISSR_HUMAN) Homo sapiens (Human). KiSS-1 receptor. URL: https:// swissmodel.expasy.org/repository/uniprot//Q969F8. 